\title{
PENINGKATAN KEAKTIFAN DAN PRESTASI BELAJAR IPS SISWA SEKOLAH DASAR DENGAN MENGGUNAKAN MODEL PEMBELAJARAN KOOPERATIF TEKNIK JIGSAW
}

\author{
Rusmawan Puji Purnomo \\ Dosen PGSD, FKIP, Universitas Sanata Dharma, Yogyakarta \\ e-mail: rusmawan2222@yahoo.comdan purnomousd@yahoo.com
}

\begin{abstract}
Abstrak: Penelitian ini betujuan untuk (1) mengetahui apakah penggunaan model pembelajaran kooperatif teknik jigsaw dapat meningkatkan aktivitas belajar IPS siswa di lima SD mitra Prodi PGSD Universitas Sanata Dharma (USD), (2) mengetahui apakah penggunaan model pembelajaran kooperatif teknik jigsaw dapat meningkatkan prestasi belajar IPS siswa di lima SD mitra Prodi PGSD USD. Penelitian ini merupakan penelitian deskriptif dengan variabel penelitian yang akan ditingkatkan adalah aktivitas belajar dan prestasi belajar siswa dengan menggunakan model pembelajaran kooperatif teknik jigsaw. Penelitian dilaksanakan di lima SD mitra Prodi PGSD USD yaitu SD Kanisius Gowongan Yogyakarta, SD Kanisius Wirobrajan Yogyakarta, SD Kanisius Kembaran Bantul, SD Negeri Denggung Sleman dan SD Negeri Tidar 7 Magelang. Data penelitian dikumpulkan dengan menggunakan metode observasi dan dokumentasi, kemudian dianalisis menggunakan analisis kuantitatif. Hasil penelitian menunjukkan bahwa: (1) aktivitas belajar IPS siswa di lima SD mitra Prodi PGSD USD mengalami peningkatan. Hal ini terlihat pada persentase: (a) aspek aktivitas bertanya kondisi awal 26\% dan pada kondisi akhir 74\%; (b) aspek aktivitas menjawab pertanyaan guru, pada kondisi awal 24\% kondisi akhir 55\%; (c) aspek aktivitas menyampaikan pendapat, pada kondisi awal 14\%, kondisi akhir 52\%; dan (d) aspek interaksi dalam kelompok, pada kondisi awal 26\%, kondisi akhir 56\%; (2) Prestasi belajar siswa di lima SD mitra Prodi PGSD USD mengalami peningkatan. Hal ini terlihat dari nilai rata-rata mata pelajaran IPS di lima SD mitra, pada kondisi awal 57,10, dan pada kondisi akhir 73,50. Capaian KKM, pada kondisi awal 29,90\% dan pada kondisi akhir $70.95 \%$. Dengan demikian dapat disimpulkan bahwa (1) penggunaan model pembelajaran kooperatif teknik jigsaw dapat meningkatkan aktivitas belajar IPS siswa di lima SD mitra prodi PGSD USD; (2) penggunaan model pembelajaran kooperatif teknik jigsaw dapat meningkatkan prestasi belajar IPS siswa di lima SD mitra prodi PGSD USD.
\end{abstract}

Kata Kunci: keaktifan belajar, prestasi belajar, model pembelajaran kooperatif teknik jigsaw

\section{PENDAHULUAN}

IPS merupakan pelajaran mengenai masyarakat yang diberikan kepada peserta didik mulai jenjang pendidikan dasar. Dengan diberikannya mata pelajaran IPS pada jenjang Sekolah Dasar (SD) diharapkan siswa memiliki kemampuankemampuan sosial seperti tergambar dalam berbagai standar kompetensi IPS SD. Murid perlu memahami IPS dengan baik, pemahaman ini tergambar dalam skor ulangan yang dicapai oleh murid yang bersangkutan. Agar pemahaman murid dapat bertahan lama maka dalam pembelajaran IPS perlu diupayakan suasana belajar aktif.

Hasil diskusi awal dengan para guru di Lima SD Mitra Prodi PGSD menunjukkan bahwa rata-rata skor ulangan mata pelajaran IPS dalam 2 tahun terakhir ini masih di bawah Kriteria Ketuntasan Minimal (KKM). Kondisi ini tampak pada Tabel. 1.

Tabel. 1 Data awal prestasi prestasi belajar IPS siswa di lima SD Mitra Prodi PGSD USD 


\begin{tabular}{|c|c|c|c|c|c|c|c|c|}
\hline \multirow[b]{3}{*}{$\begin{array}{l}\mathrm{N} \\
\mathrm{o}\end{array}$} & \multirow[b]{3}{*}{$\begin{array}{c}\text { Nama } \\
\text { Sekola } \\
\text { h }\end{array}$} & \multirow[b]{3}{*}{$\begin{array}{l}\mathrm{K} \\
\mathrm{K} \\
\mathrm{M}\end{array}$} & \multicolumn{4}{|c|}{ Tahun Pelajaran } & \multicolumn{2}{|c|}{ Data Awal } \\
\hline & & & \multicolumn{2}{|c|}{$2007 / 2008$} & \multicolumn{2}{|c|}{$2008 / 2009$} & \multirow{2}{*}{$\begin{array}{c}\text { Rerat } \\
\text { a } \\
\text { Nilai }\end{array}$} & \multirow[b]{2}{*}{$\begin{array}{l}\text { Cap } \\
\text { aian } \\
\text { KK } \\
\text { M } \\
(\%)\end{array}$} \\
\hline & & & $\begin{array}{c}\text { Rerat } \\
\text { a } \\
\text { Nilai }\end{array}$ & $\begin{array}{c}\text { Capai } \\
\text { an } \\
\text { KKM } \\
(\%)\end{array}$ & $\begin{array}{c}\text { Rerata } \\
\text { Nilai }\end{array}$ & $\begin{array}{c}\text { Capai } \\
\text { an } \\
\text { KKM } \\
(\%)\end{array}$ & & \\
\hline 1. & $\begin{array}{l}\text { SD N } \\
\text { Tidar } 7\end{array}$ & 65 & 64.14 & 52.77 & 63.03 & 58.97 & 63.58 & $\begin{array}{c}55.8 \\
7\end{array}$ \\
\hline 2. & $\begin{array}{l}\text { SD N } \\
\text { Dengg } \\
\text { ung }\end{array}$ & 65 & 56.12 & 21.21 & 58.17 & 29.27 & 57.15 & $\begin{array}{c}25.2 \\
4\end{array}$ \\
\hline 3. & $\begin{array}{l}\text { SD K } \\
\text { Wirobr } \\
\text { ajan }\end{array}$ & 68 & - & - & 60.10 & 19.07 & 60.10 & $\begin{array}{c}19.0 \\
7 \\
\end{array}$ \\
\hline 4. & $\begin{array}{l}\text { SD K } \\
\text { Gowo } \\
\text { ngan }\end{array}$ & 70 & 58.00 & 18.18 & 49.00 & 00.00 & 53.50 & 9.09 \\
\hline 5. & $\begin{array}{l}\text { SD K } \\
\text { Kemba } \\
\text { ran }\end{array}$ & 64 & 61.00 & 37.04 & 59.10 & 43.48 & 60.05 & $\begin{array}{c}40.2 \\
6 \\
\end{array}$ \\
\hline
\end{tabular}

Diduga tidak tercapainya KKM tersebut disebabkan dalam belajar IPS kurang melibatkan siswa. Kurangnya keterlibatan siswa dikarenakan guru cenderung menggunakan metode ceramah pada saat menyampiakan materi pelajaran. Permasalahan ini dicoba akan diatasi dengan menggunakan model pembelajaran kooperatif teknik jigsaw.

Pembelajaran kooperatif teknik jigsaw memfokuskan pada rasa tanggung jawab siswa terhadap pembelajaran, serta kerja sama secara kooperatif untuk mempelajari materi yang ditugaskan oleh guru. Dengan menerapkan model pembelajaran kooperatif teknik jigsaw diharapkan dapat meningkatkan aktivitas dan prestasi belajar siswa dalam pembelajaran IPS di Lima SD Mitra Prodi PGSD USD Tahun Pelajaran 2009/2010.

Berdasarkan latar belakang yang telah dipaparkan di atas, permasalahan dalam penelitian ini dirumuskan sebagai berikut: (1) apakah penggunaan model pembelajaran kooperatif teknik jigsaw dapat meningkatkan aktivitas belajar IPS siswa di lima SD mitra prodi PGSD USD tahun pelajaran 2009/2010? dan (2) apakah penggunaan model pembelajaran kooperatif teknik jigsaw dapat meningkatkan prestasi belajar IPS siswa di lima SD mitra prodi PGSD USD tahun pelajaran 2009/2010?

Penelitian ini bertujuan untuk: (1) mengetahui apakah penggunaan model pembelajaran kooperatif teknik jigsaw dapat meningkatkan aktivitas belajar IPS siswa di lima SD mitra prodi PGSD USD tahun pelajaran 2009/2010, dan (2) mengetahui apakah penggunaan model pembelajaran kooperatif teknik jigsaw dapat meningkatkan prestasi belajar IPS siswa di lima SD mitra prodi PGSD USD tahun pelajaran 2009/2010. Sedangkan manfaat penelitian ini adalah dapat menambah wawasan tentang upaya meningkatkan prestasi dan aktivitas belajar siswa khususnya dalam mata pelajara IPS SD dengan menggunakan model pembelajaran kooperatif teknik jigsaw.

\section{KAJIAN PUSTAKA}

\section{Keaktifan Siswa}

Keaktifan siswa dalam penelitian ini mengacu pada dimensi-dimensi cara belajar siswa aktif (CBSA). Dalam CBSA terdapat tingkah laku belajar yang mendasarkan pada kegiatan-kegiatan yang menggambarkan tingkat keterlibatan siswa dalam proses belajar-mengajar baik intelektual emosional maupun fisik, tingkah laku tersebut nampak pada 4 dimensi CBSA sebagai berikut (Kosasih, 1980):

1. Dimensi subjek didik, meliputi: (1) keberanian mewujudkan minat, keinginan, pendapat serta dorongandorongan yang ada pada siswa dalam proses belajar-mengajar, (2) keberanian untuk mencari kesempatan untuk berpartisipasi dalam persiapan maupun tindak lanjut suatu proses belajarmengajar, (3) kreatifitas siswa dalam menyelesaikan kegiatan belajar sehingga dapat mencapai suatu keberhasilan tertentu yang memang dirancang oleh guru, dan (4) peranan bebas dalam mengerjakan sesuatu tanpa merasa ada tekanan dari siapapun termasuk guru.

2. Dimensi guru, meliputi : (1) adanya usaha guru untuk mendorong siswa dalam meningkatkan kegairahan serta 
partisipasi siswa secara aktif dalam proses belajar-mengajar, (2) kemampuan guru dalam menjalankan peranannya sebagai inovator dan motivator, (3) sikap demokratis yang ada pada guru dalam proses belajar-mengajar, (4) pemberian kesempatan kepada siswa untuk belajar sesuai dengan cara serta tingkat kemampuan masing-masing, dan (5) kemampuan untuk menggunakan berbagai jenis strategi belajarmengajar serta penggunaan multi media.

3. Dimensi program, meliputi: (1) tujuan instruksional, konsep serta materi pelajaran yang memenuhi kebutuhan, minat serta kemampuan siswa, (2) program yang memungkinkan terjadinya pengembangan konsep maupun aktivitas siswa dalam proses belajarmengajar, dan (3) program yang fleksibel disesuaikan dengan situasi dan kondisi.

4. Dimensi situasi belajar-mengajar, meliputi: (1) situasi belajar yang menjelmakan komunikasi yang baik, hangat, bersahabat, antara guru-siswa maupun antara siswa sendiri dalam proses belajar-mengajar, dan (2) adanya suasana gembira dan bergairah pada siswa dalam proses belajar-mengajar.

\section{Prestasi Belajar}

Prestasi belajar merupakan bukti keberhasilan yang telah dicapai oleh seseorang (Winkel, 1996). Prestasi belajar dipengaruhi oleh faktor-faktor pada siswa dan faktor di luar siswa. Faktor-faktor pada siswa meliputi faktor psikis dan fisik sedangkan faktor di luar siswa meliputi pengaturan proses belajar di sekolah, faktorfaktor sosial di sekolah dan factor situasional.

Prestasi belajar dapat diukur melalui tes prestasi belajar. Tes prestasi belajar bertujuan mengungkap keberhasilan sesorang dalam belajar. Tes prestasi belajar berupa tes yang disusun secara terencana untuk mengungkap performansi maksimal subyek dalam menguasai materi yang telah diajarkan.

\section{Model Pembelajaran Kooperatif Teknik Jigsaw}

Model pembelajaran kooperatif (cooperative learning) adalah suatu strategi belajar mengajar yang menekankan pada sikap atau perilaku bersama dalam bekerja atau membantu di antara sesama dalam struktur kerjasama yang teratur dalam kelompok, yang terdiri dari dua orang atau lebih (Slavin, 2008).

Roger dan David Johnson (dalam Lie, 2007) menyebutkan unsur-unsur model pembelajaran kooperatif meliputi: (1) saling ketergantungan positif, maksudnya keberhasilan suatu karya sangat bergantung pada usaha setiap anggotanya, (2) tanggung jawab perseorangan, maksudnya setiap siswa akan merasa bertanggung jawab untuk melakukan yang terbaik, (3) tatap muka, maksudnya dalam pembelajaran kooperatif setiap kelompok harus diberikan kesempatan untuk bertatap muka dan berdiskusi, (4) komunikasi antar anggota, maksudnya para pembelajar dibekali dengan berbagai keterampilan berkomunikasi, karena keberhasilan suatu kelompok juga bergantung pada kesediaan para anggotanya untuk saling mendengarkan dan kemampuan mereka untuk mengutarakan pendapat mereka, (5) evaluasi proses kelompok, maksudnya pengajar perlu menjadwalkan waktu khusus bagi kelompok untuk mengevaluasi proses kerja kelompok dan hasil kerja sama mereka agar selanjutnya bisa bekerja sama dengan lebih efektif.

Jigsaw merupakan salah satu teknik pembelajaran kooperatif. Pembelajaran kooperatif teknik Jigsaw terdiri dari beberapa anggota dalam satu kelompok yang bertanggungjawab atas penguasaan bagian materi belajar dan mampu mengajarkan 
materi tersebut kepada anggota lain dalam kelompoknya.

Langkah-langkah penerapan teknik Jigsaw adalah sebagai berikut: (1) guru membagi suatu kelas menjadi beberapa kelompok asal, setiap siswa dalam kelompok asal diberi tugas mempelajari salah satu bagian materi pembelajaran, semua siswa dengan materi pembelajaran yang sama belajar bersama dalam kelompok ahli. (2) dalam kelompok ahli, siswa mendiskusikan bagian materi pembelajaran yang sama, serta menyusun rencana bagaimana menyampaikan kepada temannya jika kembali ke kelompok asal.

\section{Hakikat IPS}

Ilmu Pengetahuan Sosial (IPS) adalah pelajaran mengenai masyarakat yang didiberikan kepada peserta didik mulai jenjang pendidikan dasar. Disiplin IPS merupakan kajian yang bersifat praktis. Bahan-bahan pelajaran IPS dipadu dari unsur-unsur yang diambil dari berbagai disiplin ilmu-ilmu sosial (social sciences). Gambaran tentang hubungan dari berbagai unsur atau aspek kemasyarakatan dalam IPS disajikan dalam bentuk terpadu atau terintegrasi.

IPS mengkaji seperangkat peristiwa, fakta, konsep, dan generalisasi yang berkaitan dengan isu sosial. Pada jenjang SD/ MI mata pelajaran IPS memuat materi Geografi, Sejarah, Sosiologi, dan Ekonomi. Mata pelajaran IPS disusun secara sistematis, komprehensif, dan terpadu dalam proses pembelajaran menuju kedewasaan dan keberhasilan dalam kehidupan di masyarakat. Dengan pendekatan tersebut diharapkan peserta didik akan memperoleh pemahaman yang lebih luas dan mendalam pada bidang ilmu yang berkaitan (Permendiknas nomor 22 tahun 2006).

Ruang lingkup mata pelajaran IPS di SD meliputi aspek-aspek sebagai berikut.

a. Manusia, Tempat, dan Lingkungan

b. Waktu, Keberlanjutan, dan Perubahan c. Sistem Sosial dan Budaya

d. Perilaku Ekonomi dan Kesejahteraan.

Secara rinci ruang lingkup tersebut dijabarkan menjadi beberapa standar kompetensi IPS di SD. Standar kompetensi adalah kemampuan yang dapat dilakukan atau ditampilkan untuk satu mata pelajaran; kompetensi dalam mata pelajaran tertentu yang harus dimiliki oleh siswa; kemampuan yang harus dimiliki oleh lulusan dalam suatu mata pelajaran. Kemampuan yang dimaksud dapat meliputi pengetahuan keterampilan maupun sikap. Pembelajaran IPS pada tingkat SD diupayakan adanya keterpaduan diantara mata pelajaran dalam rumpun IPS.

\section{METODE PENELITIAN}

\section{Jenis Penelitian}

Penelitian ini merupakan penelitian deskriptif. Hasil penelitian ini dimaksudkan untuk memberikan gambaran tentang peningkatan aktivitas belajar dan prestasi belajar IPS siswa di lima SD mitra PGSD USD dengan menggunakan model pembelajaran kooperatif teknik jigsaw.

\section{Variabel Penelitian dan Definisi Operasional Variabel}

Variabel yang akan ditingkatkan dengan menggunakan model pembelajaran kooperatif teknik jigsaw dalam penelitian ini adalah aktivitas belajar dan prestasi belajar siswa. Aktivitas belajar adalah tingkah laku belajar yang mendasarkan pada kegiatan-kegiatan yang menggambarkan tingkat keterlibatan siswa dalam proses belajar-mengajar. Sedangkan prestasi belajar adalah bukti keberhasilan yang telah dicapai oleh siswa yang dibuktikan oleh skor ulangan.

\section{Tempat dan Waktu Penelitian}

Penelitian tentang penggunaan model pembelajaran kooperatif teknik jigsaw untuk meningkatkan aktivitas dan prestasi 
belajar IPS siswa dilaksanakan di lima SD mitra Prodi PGSD USD yaitu SD Kanisius Gowongan Yogyakarta, SD Kanisius Wirobrajan Yogyakarta, SD Kanisius Kembaran Bantul, SD Negeri Denggung Sleman dan SD Negeri Tidar 7 Magelang. Waktu pelaksanaan penelitian ini adalah bulan November 2009 s.d. Oktober 2010.

\section{Subyek Penelitian}

Subyek penelitian ini adalah siswa kelas IV SD Kanisius Gowongan Yogyakarta, siswa kelas IV SD Kanisius Wirobrajan Yogyakarta, siswa kelas V SD Kanisius Kembaran Bantul, siswa kelas IV SD Negeri Denggung Sleman dan siswa kelas V SD Negeri Tidar 7 Magelang. Penentuan subyek penelitian didasari oleh pertimbangan: (1) kelas VI lebih konsentrasi pada persiapan Ujian Nasional sehingga tidak diijinkan untuk dijadikan subjek penelitian, dan (2) kelas I, II,III SD pendekatan penyampaiannya dengan pembelajaran tematik sehingga tidak bisa fokus pada mata pelajaran IPS. Sedangkan penentuan SD didasari pada keterwakilan akreditasi sekolah.

\section{Metode Pengumpulan Data}

Data yang dikumpulkan dalam penelitian ini adalah data primer dan data sekunder. Metode pengumpulan data yang digunakan dalam penelitian ini antara lain (1) Observasi, metode ini digunakan dalam rangka mencari data tentang aktivitas siswa dalam pembelajaran IPS, (2) dokumentasi, metode ini digunakan dengan mengambil atau mencatat data tentang prestasi belajar IPS.

\section{Pengolahan Data dan Teknik Analisis Data}

Data dalam penelitian ini dianalisis menggunakan analisis kuantitatif. Analisis kuantitatif ditempuh dengan: (1) membandingkan rata-rata prestasi belajar IPS siswa di lima SD mitra sebelum dan se- sudah dikenai tindakan baik persekolah maupun keseluruhan, (2) membandingkan frekwensi aktifitas siswa di lima SD mitra sebelum dan sesudah dikenai tindakan baik persekolah maupun keseluruhan. Efektivitas penelitian ini akan dilihat dari aktivitas dan prestasi belajar siswa.

\section{Keaktifan belajar}

Karena keterbatasan sumber daya yang ada pada peneliti, maka penelitian keaktifan belajar siswa dalam mata pelajaran IPS ditetapkan atau dibatasi pada dimensi subyek didik jumlah dan frekwensi siswa dalam aspek-aspek: (1) bertanya pada guru, (2) menjawab pertanyaan/tugas dari guru, (3) berpendapat, dan (4) berinteraksi di dalam kelompok

\section{1) Prestasi belajar}

Prestasi belajar dinyatakan dalam nilai rata-rata yang diperoleh siswa. Nilai rata-rata dihitung dengan rumus:

$$
\mathrm{M}=\frac{\sum \mathrm{X}}{\mathrm{N}}
$$

Keterangan:

$\mathrm{M}=$ Nilai rata-rata

$\Sigma X=$ Jumlah nilai siswa satu kelas

$\mathrm{N}=$ Jumlah siswa

\section{HASIL PENELITIAN DAN PEMBAHASAN}

\section{Aktivitas Belajar IPS Siswa di Lima SD Mitra Prodi PGSD USD dengan Model Pembelajaran Kooperatif Teknik Jigsaw Jumlah siswa yang aktif bertanya pada guru pada kondisi awal sebanyak $25,2 \%$, pada akhir siklus I sebanyak $46,3 \%$ siswa, dan pada akhir siklus II sebanyak $58,5 \%$. Dengan demikian terkait dengan ke- aktifan bertanya, terjadi peningkatan pada akhir siklus I $21,1 \%$ dan pada akhir siklus II $12,2 \%$. Dengan demikian terlihat bahwa rata-rata kenaikan persentase jumlah siswa yang bertanya sebesar 16,7\%. Kenaikan}


jumlah siswa yang bertanya pada akhir siklus II lebih rendah dibandingkan pada akhir siklus I, hal ini diduga karena siswa terlalu asyik dalam kegiatan kelompok. Meskipun jumlah siswa yang bertanya meningkat, tetapi masih ada $41,5 \%$ siswa yang tidak bertanya. Hal ini diduga disebabkan belum terbiasanya siswa untuk bersikap kritis terhadap sesuatu.

Jumlah siswa yang aktif menjawab pertanyaan/tugas dari guru pada kondisi awal sebanyak $23,6 \%$, pada akhir siklus I sebanyak 48,8\% siswa, dan pada akhir siklus II sebanyak $63,4 \%$. Dengan demikian terkait dengan keaktifan menjawab pertanyaan dari guru, terjadi peningkatan pada akhir siklus I 25,2\% dan pada akhir siklus II $14,6 \%$. Dengan demikian terlihat bahwa rata-rata kenaikan persentase jumlah siswa yang bertanya sebesar 19,9\%. Meskipun jumlah siswa yang aktif menjawab pertanyaan guru meningkat, tetapi masih ada $36,6 \%$ siswa yang tidak aktif menjawab. Hal ini diduga disebabkan oleh siswa lebih memusatkan perhatian pada kegiatan kelompok masing-masing.

Jumlah siswa yang berpendapat pada kondisi awal sebanyak 13,8\%, pada akhir siklus I sebanyak $26 \%$ siswa, dan pada akhir siklus II sebanyak 53,7\%. Dengan demikian terkait dengan keaktifan berpendapat, terjadi peningkatan pada akhir siklus I $12,2 \%$ dan pada akhir siklus II $27,6 \%$. Dengan demikian terlihat bahwa rata-rata kenaikan persentase jumlah siswa yang berpendapat sebesar 19,9\%. Meskipun jumlah siswa yang berpendapat meningkat, tetapi masih ada $46,3 \%$ siswa yang tidak berpendapat. Hal ini disebakan oleh siswa lebih memusatkan perhatian pada kegiatan kelompok masing-masing.

Jumlah siswa yang berinteraksi didalam kelompok pada kondisi awal sebanyak $26 \%$, pada akhir siklus I sebanyak $65,9 \%$ siswa, dan pada akhir siklus II sebanyak $84,6 \%$. Dengan demikian terkait dengan keaktifan siswa berinteraksi di- dalam kelompok, terjadi peningkatan pada akhir siklus I 39,8\% dan pada akhir siklus II $18,7 \%$. Dengan demikian terlihat bahwa rata-rata kenaikan persentase jumlah siswa yang berinteraksi di dalam kelompok sebesar 26,6\%. Kenaikan jumlah siswa yang berinteraksi dalam kelompok pada akhir siklus II lebih rendah dibandingkan pada akhir siklus I, meskipun demikian jumlah keseluruhan siswa yang telah berinteraksi dalam kelompok mencapai $84,6 \%$ sehingga jumlah siswa yang tidak berinteraksi di dalam kelompok tinggal 15,4\% .

Frekuensi keaktifan bertanya pada kondisi awal sebanyak 53 kali, pada akhir siklus I 124 kali, dan pada akhir siklus II 176 kali. Dengan demikian dilihat dari frekuensi keaktifan bertanya siswa, terjadi peningkatan akhir siklus I 71 kali dan pada akhir siklus II 52 kali. Dengan demikian terlihat bahwa kenaikan frekuensi keaktifan bertanya pada akhir penelitian rata-rata sebesar 61,5 kali.

Frekuensi keaktifan menjawab pertanyaan dari guru pada kondisi awal sebanyak 56 kali, pada akhir siklus I 108 kali, dan pada akhir siklus II 164 kali. Dengan demikian dilihat dari frekuensi keaktifan menjawab pertanyan dari guru, terjadi peningkatan akhir siklus I 52 kali dan pada akhir siklus II 56 kali. Dengan demikian terlihat bahwa kenaikan frekuensi keaktifan menjawab pertanyaan dari guru pada akhir penelitian rata-rata sebesar 54 kali.

Frekuensi keaktifan berpendapat pada kondisi awal sebanyak 31 kali, pada akhir siklus I 50 kali, dan pada akhir siklus II 101 kali. Dengan demikian dilihat dari frekwensi keaktifan berpendapat siswa, terjadi peningkatan akhir siklus I 19 kali dan pada akhir siklus II 51 kali. Dengan demikian terlihat bahwa kenaikan frekuensi keaktifan berpendapat pada akhir penelitian rata-rata sebesar 75,5 kali.

Frekuensi keaktifan berinteraksi dalam kelompok pada kondisi awal sebanyak 41 kali, pada akhir siklus I 145 kali, 
dan pada akhir siklus II 192 kali. Dengan demikian dilihat dari frekwensi keaktifan berinteraksi dalam kelompok, terjadi peningkatan akhir siklus I 104 kali dan pada akhir siklus II 47 kali. Dengan demikian terlihat bahwa kenaikan frekuensi keaktifan berinteraksi dalam kelompok pada akhir penelitian rata-rata sebesar 75,5 kali.

Dari analisis data tersebut, terlihat bahwa keaktifan belajar IPS siswa lima SD Mitra Prodi PGSD USD Tahun Pelajaran 2009/2010 dengan model pembelajaran kooperatif teknik jigsaw meningkat baik jumlah maupun frekuensinya.

\section{Kepuasan Belajar IPS Siswa di Lima SD Mitra Prodi PGSD USD dengan Model Pembelajaran Kooperatif Teknik Jigsaw}

Persentase rata-rata jumlah siswa terkait dengan kepuasan belajar IPS siswa di Lima SD Mitra Prodi PGSD USD tahun pelajaran 2009/2010 dengan model pembelajaran kooperatif teknik jigsaw pada kondisi awal, siswa yang merasa senang sebanyak 46,7\%, pada akhir siklus I 86,8\%, dan pada akhir siklus II 97,2\%. Dengan demikian dilihat dari jumlah siswa yang merasa senang dalam belajarnya, terjadi peningkatan akhir siklus I 40,1\% dan pada akhir siklus II 10,4\%. Dengan demikian terlihat bahwa kenaikan jumlah siswa yang merasa senang dalam belajarnya pada akhir penelitian rata-rata sebesar $92 \%$.

\section{Prestasi Belajar IPS Siswa di Lima SD Mitra Prodi PGSD USD dengan Model Pembelajaran Kooperatif Teknik Jigsaw}

Nilai rata-rata IPS siswa lima SD Mitra Prodi PGSD USD tahun pelajaran 2009/2010 dengan model pembelajaran kooperatif teknik jigsaw pada kondisi awal 57,10, pada akhir siklus I 67,00. Persentase jumlah siswa yang memperoleh nilai di bawah rata-rata sebanyak $44,9 \%$ sedangkan persentase jumlah siswa yang memperoleh nilai sama dengan atau lebih besar dari ratarata sebesar $55,1 \%$. Sedangkan pada akhir siklus II nilai rata-rata 76,00. Persentase jumlah siswa yang memperoleh nilai di bawah rata-rata sebanyak 50,4\% sedangkan persentase jumlah siswa yang memperoleh nilai sama dengan atau lebih besar dari ratarata sebesar 49,6\%. Dengan demikian dilihat dari nilai rata-rata siswa, terjadi peningkatan akhir siklus I 9,9 dan pada akhir siklus II 9,0. Dengan demikian terlihat bahwa kenaikan nilai rata-rata siswa pada akhir penelitian rata-rata sebesar 9,45. Persentase jumlah siswa yang mencapai nilai rata-rata pada siklus II menurun, hal ini dikarenakan rata-rata nilai untuk siklus II lebih tinggi dibandingkan siklus I (67:76).

Dari ke-lima SD tersebut, kenaikan nilai rata-tertinggi pada akhir penelitian $(13,8)$ ada pada SD Kanisius Gowongan. Hal ini diduga karena jumlah siswa di SD Kanisius Gowongan relatif kecil (16 siswa) sehingga pengelolaan pembelajarannya bisa lebih efisien dan efektif. Sedangkan kenaikan nilai rata-rata terendah pada akhir penelitian $(5,1)$ ada pada SD Kanisius Wirobrajan. Hal ini diduga jumlah siswa paling banyak (33 siswa).

Persentase jumlah siswa yang mencapai KKM pada capaian belajar IPS siswa lima SD Mitra Prodi PGSD USD tahun pelajaran 2009/2010 dengan model pembelajaran kooperatif teknik jigsaw pada kondisi awal 29,9\%, pada akhir siklus I $62,7 \%$ dan pada akhir siklus II 79,2\%. Dengan demikian dilihat dari persentase jumlah siswa yang mencapai KKM, terjadi peningkatan akhir siklus I $25.2 \%$ dan pada akhir siklus II 16,5\%. Dengan demikian terlihat bahwa persentase jumlah siswa yang mencapai KKM pada akhir penelitian ratarata sebesar $70.9 \%$.

Dari ke-lima SD tersebut, persentase jumlah siswa yang mencapai KKM tertinggi pada akhir penelitian $(62,8 \%)$ ada 
pada SD Kanisius Gowongan. Hal ini diduga karena jumlah siswa di SD Kanisius Gowongan lebih sedikit dibandingkan SD yang lain, sehingga pengeloaan pembelajarannya bisa lebih efisien dan efektif. Sedangkan persentase jumlah siswa yang mencapai KKM terendah pada akhir penelitian $(15,3 \%)$ ada pada SD Negeri Tidar 7. Hal ini diduga jumlah siswa yang tergolong besar.

\section{Refleksi}

Hal-hal umum yang dijumpai selama proses pembelajaran pada siklus pertama di lima SD mitra, antara lain: (1) model pembelajaran ini belum mampu meningkatkan keterlibatan siswa secara merata; (2) siswa masih bingung dalam menerapkan model pembelajaran pembelajaran kooperatif teknik jigsaw. Kebingungan ini terlihat pada saat siswa kembali kedalam kelompok asal, siswa bingung saat melakukan diskusi, siswa cenderung main sendiri dan tidak memperhatikan temannya saat menjelaskan. Hal ini disebabkan siswa baru pertama kali mengalami kegiatan belajar mengajar dengan menggunakan model pembelajaran ini; (3) kelompok siswa yang terdiri dari delapan (6-8) orang dirasa kurang efektif dalam melaksanakan pembelajaran. Kondisi ini diatasi pada siklus kedua dengan tindakan sebagai berikut: (1) jumlah anggota kelompok diperkecil (4 siswa), (2) guru menjelaskan tentang model pembelajaran kooperatif teknik jigsaw secara lebih mendetail; (3) diusahakan untuk meningkatkan keterlibatan siswa. Dilihat dari capaian prestasi belajar, penggunaan model pembelajaran ini meningkatkan prestasi belajar siswa sebesar 15,9, yaitu dari kondisi awal 57,1 menjadi 67,0 pada siklus pertama.

Hal-hal umum yang dijumpai selama proses pembelajaran pada siklus kedua di lima SD mitra, antara lain: (1) model pembelajaran ini mampu meningkatkan keterlibatan siswa secara merata; (2) siswa menikmati penerapan model pembelajaran pembelajaran kooperatif teknik jigsaw. Hal ini terlihat pada saat siswa aktif mengikuti diskusi yang berlangsung di kelompok ahli maupun dalam kelompok asal, siswa lebih berinteraksi dengan siswa yang lain dan lebih bertanggung jawab menyampaikan hasil diskusi dari kelompok ahli kelompok asal serta aktif mencari dan menemukan data yang diperlukan untuk mengerjakan tugas di kelompok ahli. Dilihat dari capaian prestasi belajar, penggunaan model pembelajaran ini meningkatkan rata-rata prestasi belajar siswa sebesar 11, yaitu dari akhir siklus pertama sebesar 67,00 menjadi 76,00 pada akhir siklus kedua.

\section{KESIMPULAN DAN SARAN}

\section{Kesimpulan}

1. Penggunaan model pembelajaran kooperatif teknik jigsaw dapat meningkatkan aktivitas belajar IPS siswa di lima SD mitra prodi PGSD USD. Hal ini terlihat pada persentase: (1) aspek aktivitas bertanya kondisi awal $26 \%$ dan pada kondisi akhir 74\%; (2) aspek aktivitas menjawab pertanyaan guru, pada kondisi awal 24\% kondisi akhir 55\%; (3) aspek aktivitas menyampaikan pendapat, pada kondisi awal 14\%, kondisi akhir 52\%; dan (4) aspek interaksi dalam kelompok, pada kondisi awal 26\%, kondisi akhir $56 \%$.

2. Penggunaan model pembelajaran kooperatif teknik jigsaw dapat meningkatkan prestasi belajar akademik IPS siswa di lima SD mitra prodi PGSD USD. Hal ini terlihat dari nilai rata-rata mata pelajaran IPS di lima SD mitra, kondisi awal 57,10, kondisi akhir 73,50. Capaian KKM, kondisi awal 29,90 \% dan pada kondisi akhir $70.95 \%$ 


\section{Saran}

1. Para guru hendaknya berusaha untuk menguasai model pembelajaran kooperatif teknik jigsaw karena penggunaan model pembelajaran tersebut terbukti dapat meningkatkan keterlibatan siswa dan prestasi belajar.

2. Kelompok Kerja Guru (KKG) hendaknya merancang kegiatan yang dapat membekali guru untuk mengusai model pembelajaran kooperatif teknik jigsaw.

3. Peneliti lain disarankan untuk melakukan penelitian terkait model pembelajaran kooperatif teknik jigsaw dengan melihat dimensi lain.

\section{DAFTAR PUSTAKA}

Fakih Samlawi dan Benyamin Maftuh. 1998. Konsep Dasar IPS. Jakarta: Depdikbud.

Kosasih, Djahiri, A. 1980. CBSA dalam Ilmu Pengetahuan Sosial. Jakarta: Depdikbud.

Lie, Anita. 2007. Cooperative Learning. Jakarta : Grasindo.

NN. 2006. Permendiknas No. 26 tentang Standar Kompetensi Lulusan SD/MI. Jakarta.

Nur Asma. 2006. Model Pembelajaran Kooperatif. Jakarta: Direktorat Ketenagaan.

Slavin, Robert E. 2008. Cooperative Learning Teori, Riset dan Praktik (terjemahan). Bandung: Nusa Media.

Suharsimi Arikunto. (1996). Prosedur Penelitian Suatu Pendekatan Praktek. Jakarta: Rineka Cipta.

Winkel. 1996. Psikologi Pengajaran. Jakarta: Grasindo.

Yusuf Wibisono. 2005. Metode Statistik. Yogyakarta: Gadjah Mada University Press 